\title{
Transmodernity: Paradigm Reconstruction of Islamic Education
}

\author{
Mohd. Arifullah* \\ Postgraduate School \\ UIN Sultan Thaha Saifuddin \\ Jambi, Indonesia \\ *simulakra.arif@gmail.com \\ Bahrul Ulum \\ Shari'ah and Law Faculty \\ UIN Sultan Thaha Saifuddin \\ Jambi, Indonesia \\ Irul70@yahoo.com
}

\author{
Siti Raudhatul Jannah, Jamaluddin \\ Tarbiyah and Education Faculty \\ UIN Sulthan Thaha Saifuddin \\ Jambi, Indonesia \\ s.raudhatuljannah74@gmail.com
}

\author{
M. Ied al-Munir \\ Ushuluddin and Religious Study Faculty \\ UIN Sulthan Thaha Saifuddin \\ Jambi, Indonesia \\ m.iedalmunir@gmail.com
}

\begin{abstract}
This article aimed to show the differences and uniqueness of scientific paradigms in Islamic and Western education systems, which are usually confronted head-on in a conflict dimension. The writers tried to provide a scientific paradigm that influenced tradition and education in the Islamic and Western worlds. The concept of education that was designed must be based on the basic needs of humans who want to know something new, but still cannot be separated from Islamic basic values. This study used qualitative research with data collection techniques was a documentation. The main source of data in this research was information, both in the form of manual text and digital text. This study also used triangulation techniques, so the data collected can be guaranteed. The technique of Data analysis was content analysis. Based on the study that had been conducted, it was found that science was the result of naturalization or contextualization of science with cultural values and the socio-cultural dimension of society, so it must be understood as something unique and historical. The Islamic education paradigm must align Islamic science with Western science, but it was not a new paradigm of Islamic education but a reconstruction effort towards the quality of Islamic education paradigm. The reconstruction of Islamic education aligns the applicability between Islamic normativity and the advancement of science, as well as the demands of locality in producing Islamic scientific structures.
\end{abstract}

Keywords-paradigm, transmodernity, contextualization, hegemony, multi-modernity

\section{INTRODUCTION}

Science requires openness to multidimensional approaches including normative approaches that acknowledge unobservable metaphysical truths. The more open science was the more universal it would be. Through this article the authors tried to avoid the nuances of conflict in seeing the differences between Islamic and modern scientific paradigms (Positivism), where the Islamic scientific paradigm in modernity must be able to cross the threshold of ideological locality, territory, culture, and paradigm fights. Therefore, talked about the debate on scientific paradigms had to be resolved and there was no need for further review.

In this context, Transmodernity could then be promoted into an alternative approach, considering that this tradition of thought was critical of the modern Western tradition of science and the tradition of Islamic science, adapts to local traditions. So that it was a thought rooted in the Islamic scientific tradition, had a modern perspective, and respects local traditions. In it, each tradition was considered equal, its advantages and disadvantages [1]. In this context, the critical response of transmodernity to the writer's various episteme buildings was the initial foundation for exploring the conceptual, historical, and practical paradigm of Islamic science openess. In turn, the paradigm of Islamic science in the perspective of transmodernity became important to be appointed and used as the basis for reformulating the paradigm of Islamic science. This was needed during efforts to rebuild Islamic scientific traditions that practically lived in Islamic educational institutions which currently appear to be improving in the development of their scientific traditions openly by accommodating efforts to integrate science.

\section{MethodS}

The focus of this research was to provide a picture of Transmodernity (Paradigm Reconstruction Threats Islamic Education). Thus, the most suitable approach to this research was a qualitative approach where the data collection technique was documentation. Thus, the data used and studied in this study comes from text, both in the form of manuscripts (books, 
magazines, journals, newspapers, etc.) or digital text. Qualitative data was data that is expressed in the form of words, sentences, and pictures [2]. The main requirement of data source texts in this study was that they were relevant to Transmodernity (Paradigm Reconstruction Threats Islamic Education. Therefore, the data from qualitative research could be form of spoken words or written words about observable human behavior [3]. Before the analysis, the data were validated using triangulation techniques. This was as stated by Bachri [4] that checking data to gain confidence in the correctness of data in qualitative research could be done by triangulation. Using content analysis techniques. However, the analysis activities in this study were carried out together with the data collection itself. This refers to the opinion of Rijali [5] that qualitative data analysis activities were integrated with data collection activities, data reduction, data presentation, and conclusion of results research. This was also in line with the opinion of Suyitno [6] that qualitative research was a descriptive research and tend to use an inductive analysis approach.

\section{DISCUSSION}

\section{A. The "New" Paradigm of Islamic Education Development}

Transmodernity was a complex approach, referring to the thought of Rosa Maria Rodriquez Magda which was later used by Marx Luyckx Ghisi (b. 1942 AD) as an approach to seeing and providing decisions in various areas of life. Transmodernity had criticized various modernity theses through the deconstruction of Eurocentrism and Postmodernism, which were the dividing walls of modern ideology. Transmodernity in this case was no man's land which frees everyone to seek the truth and make it his belief. Here each person was freed from various categories of thought to find his way in a world of chaos [7].

Based on its contact with modernity and acceptance of various previous forms of thought, Transmodernity was essentially an attempt to maintain the best of modernity and at the same time try to surpass it. Therefore, transmodernity was not a linear project in progress from para-modern to postmodern, but a project that transcends modernity and postmodernity into a new place. In short, transmodernity was an attempt to transfer modernity from a level of chaos to an orderly society [8].

The frame of mind of transmodernism could be expressed as modernity that recognizes transcendence and postmodernism without chaos, it was the result of dialectics between Traditionalism, Modernism, and Postmodernism which at the same time try to build an epistemological system based on and beyond the three. Transmodernity could also be seen as a synthesis between the past, present, and future projects for the present context [9]. For Sardar [10], this transmodernity was a project directed at overcoming the crisis of modernity and postmodernity. This meant that transmodernity moved beyond modernity and Postmodernism, it transcends both of them and brings changed from both of them to new, different states.
Transmodernity as a concept was designed to form positive elements of self-renewal and self-reform in a world full of diversity, social, economic, or cultural status. Transmodernity wanted to change the transcultural, so that all cultures could play a role in change. When modernity saw certain cultures as exclusive in negative terms, transmodernity saw all cultures as forces that contain both positive and negative values and could be transformed into an essential part of the continuation of change. Traditional societies were understood to be modernized; they could define the boundaries of the meaning of modernity in their context to achieve progress in the perspective of their respective traditional values and norms [11]. In this context the Islamic science paradigm based on the transmodernity point of view could be reconstructed through three steps, they were (1) Re-actualization of shari'a as the basis of the scientific paradigm; (2) Introduction to the world as it is, and; (3) Establishment of Islamic science [12]. In this way, the paradigm of Islamic science that leads to Islamic science could be grown in the world of Islamic education.

The formation of a paradigm of Islamic science in the context of Islamic science was important with several arguments, namely: (1) different civilizations to have produced different sciences; (2) Islamic science had its uniqueness and characteristics which differ from Western science which had proven to be a threat to humanity; (3) Western science would not be able to meet the physical, cultural and spiritual needs of the Muslim community [12]. Some of these arguments were expected to make Muslims aware of the uniqueness of the paradigm of Western and Islamic science, both in the aspects of civilization, history, human vision, and basic needs as a cultural system. In this case, the world of Islamic education was expected to develop its science according to the needs, history, humanitarian vision and worldview of Islam, namely science that departs from local needs and integrated with the cultural system and Islamic values. The science was essentially not only directed towards the development of the Islamic world but also able to fulfill a prophetic-ethical vision that was friendly to humans and the world.

Islamic science in today's context was non-negotiable and must be constructed following the Islamic worldview, directed to return science to its goal as a means of seeking and loving truth for the benefit of humans. Islamic science was a science that was enforced by Islamic methods that gave high respect for humans and nature in a bandage of morality. The uniqueness of Islamic science had distinguished it from other sciences, as well as an answer in meeting the needs and demands of the Muslim community [12]. Furthermore, it could be noted that Islamic science was a science that bound by universal Islamic values, especially the value of tauhid [13].

Nevertheless, Islamic science was not an apology attempt to justify science through Islamic normativity like Bucialism, nor it a wave of Muslim mystical intellectuals trying to revive traditional Muslim treasures through Sufism, nor was the Islamization movement of science trying to place a particular Islamic understanding of science. Islamic science was an organized and systematic scientific framework for achieving 
knowledge based on experiments and universal experiences across cultures. In it, the wealth of scientific tradition (contemporary) was not forgotten as the basis for the formation of Islamic science, the theory and results of classical science scientific activities were directed and updated to achieve contemporary science. The content of Islam in science was the values and assumptions that shape science-based on the Islamic worldview [12].

In summary, Islamic science that needs to be developed in the world of contemporary Islamic education was the science that based on the Islamic worldview, where tauhid was used as a macro paradigm of Islamic science in connecting all knowledge in an organic unity, complemented by an awareness of the future that was mediated in ways and goals. Science provided space for the growth of a variety of scientific methods and puts forward a universal polymath scientific model [14]. Thus, Islamic science in principle was the application of Islamic values in various scientific activities which were recognized as part of worship [15]. So that Islamic values did not only become faith alone but could manifest as a paradigm [16] that directs the view of the life of the people in their daily lives.

\section{CONCLUSION}

Transmodernity needs to be seriously considered as an approach in the reconstruction of the Islamic science paradigm amidst the weaknesses of the scientific paradigm today because it can transcend modernity and postmodernity and respect the plurality of traditions at the same time. The final result of this reconstruction was expected to produce scientific products that were following the Islamic worldview, which was said to be Islamic science. Namely, science developed based on the worldview or universal Islamic values understood in its openness to modernity and culture. It was built to meet the needs and answer contemporary problems faced by the Muslim community, to provide space for the exploration of the truth from various sources that do not contradict the basic principles of Islam. Islamic science which accommodates the lights of truth contained in the scientific treasures of Islam, modern and locality were also expected to be accepted globally and provide theoretical, practical, and ethical used values for the advancement of human civilization. Furthermore, Islamic science should not only exist in theoretical but also practical discourse, which is translated into the world of Islamic education, therefore at a later stage, efforts were needed to translate this discourse into applicable actions to overcome various problems. A locality scale as well as transnational within the Muslim community.

\section{ACKNOWLEDGMENT}

This research was conducted by involving various parties, either directly or indirectly. Therefore, the authors would like to express their deepest gratitude and appreciation to all parties involved in the research to writing reports and publication of research results. The author's gratitude and high appreciation to the Chancellor of the State Islamic University of Sulthan Thaha Saifuddin Jambi and all contributors who actively participated in this research. Hopefully this research could provide positive benefits and contributions to the development of education and science in the Islamic world for a more modern Islam in education.

\section{REFERENCES}

[1] R. Appignanesi, C. Garratt, Z. Sardar, and P. Curry, Postmodernism for beginners. Icon Books Company, 1995.

[2] Sugiyono. Metode Penelitian Kuantitatif, Kualitatif dan R\&D. Bandung: Alfabeta, 2018.

[3] I. Agusta, "Teknik Pengumpulan dan Analisis Data Kualitatif. Pusa Penelitian Sosial Ekonomi”, Litbang Pertanian, Bogor, vol. 27, 2003

[4] B.S. Bachri, "Meyakinkan validitas data melalui triangulasi pada penelitian kualitatif," Jurnal teknologi pendidikan, vol. 10, no. 1, pp. 46$62,2010$.

[5] A. Rijali, "Analisis data kualitatif.,"Alhadharah: Jurnal Ilmu Dakwah, vol. 17, no. 33, pp. 81-95, 2019.

[6] Suyitno, "Penelitian Kualitatif,” Journal Equilibrium, 2009

[7] J. Rifkin, The European dream: How Europe's vision of the future is quietly eclipsing the American dream. John Wiley \& Sons, 2013.

[8] Z. Sardar, Islam and the West in a Transmodern World. Article on Contemporary, 2004.

[9] E.D. Dussel and A. Fornazzari, "World-system and" trans"-modernity," Nepantla: views from South, vol. 3, no. 2, pp. 221-244, 2002

[10] Z. Sardar, S. Inayatullah, and G. Boxwell, Islam, Postmodernism and Other Futures a Ziauddin Sardar Reader. London-Sterling Virginia: Pluto Pers, 2003.

[11] S. Bagaeen and O. Uduku, Gated communities: social sustainability in contemporary and historical gated developments. Routledge, 2010

[12] Z. Sardar, How do you know? Reading Ziauddin Sardar on Islam, science and cultural relations. London: Pluto Pers, 2019.

[13] M.Y.H. Othman, "Islamic science (tawhidic): Toward sustainable development," イスラーム世界研究: Kyoto Bulletin of Islamic Area Studies, vol. 7, pp. 110-123, 2014

[14] M.A. Anees, "What Islamic Science is Not," MAAS Journal of Islamic sciences, vol. 2, no. 1, pp. 19-20, 1986

[15] Y.M. Faruqi, "Islamic View of Nature and Values: Could These Be the Answer to Building Bridges between Modern Science and Islamic Science," International Education Journal, vol. 8, no. 2, pp. 461-469, 2007

[16] C. Ball and A. Haque, "Diversity in religious practice: Implications of Islamic values in the public workplace," Public Personnel Management, vol. 32, no. 3, pp. 315-330, 2003. 